\title{
Die boek Josua gelees teen 'n na-eksiliese agtergrond
}

\author{
G C Lindeque \& A P B Breytenbach ${ }^{1}$ \\ Fakulteit Teologie \\ Universiteit van Pretoria
}

\begin{abstract}
Reading the book of Joshua against a post-exilic background

This article argues that the book of Joshua portrays the idealistic views held by the post-exilic community on the history of Israel. The book displays remarkable similarities with Third Isaiah and with narratives from the post-exilic period. By reading the book of Joshua against a post-exilic background, it obtains theological significance, not as a historical account of the occupation of the land, but as a call for the acceptance of foreigners into the community of the people of $\mathrm{YHWH}$, as well as for the decentralization of religious power. The book owes its final form to a marginalized group, who were in conflict with the religious leaders in Jerusalem. The book of Joshua functioned as a contra-narrative against the exclusive claims made by the returning exiles.
\end{abstract}

\section{INLEIDING}

In 'n sekere sin was die boek Josua nog altyd die slagoffer van sy posisie in die kanon. Strange (1993:140) het al reeds gewys op die eienaardige posisie van die boek in die kanon. Dit sou nie regtig 'n verskil mak aan die vloei van die verhaal indien die boek Josua uitgelaat word nie, aangesien daar in Rigters 1 wel 'n berig oor die inname van die land voorkom. Die boek Josua is dikwels in die verlede as deel van 'n groter korpus verklaar. Die klem in die navorsing het veral geval op die literêre voorgeskiedenis van

\footnotetext{
1 Hierdie artikel is gebaseer op die DD-proefskrif van G C Lindeque, getitel "Die boek Josua gelees teen 'n na-eksiliese agtergrond." Die proefskrif is voorberei onder promotorskap van prof dr A P B Breytenbach, Fakulteit Teologie, Universiteit van Pretoria (2001).
} 
die boek as deel van 'n groter geheel. Die probleem is dat die boek Josua daarmee by voorbaat vanuit 'n bepaalde perspektief verklaar is. Die navorsingsgeskiedenis is 'n duidelike bewys hiervan.

Noort (1998) bied 'n baie volledige oorsig oor die navorsingsgeskiedenis en probleemvelde van die boek Josua. Hy kom tot die gevolgtrekking dat die navorsing hoofsaaklik in twee kategorieë verdeel kan word naamlik voor en na Martin Noth (Noort 1998:60). Daarmee word die deurslaggewende rol wat die navorsing van Noth in die verstaan van die boek Josua gespeel het, beklemtoon. In die tyd voor Noth is die boek Josua hoofsaaklik as die slot van die Heksateug beskou, terwyl Noth die navorsing in 'n radikaal nuwe rigting gestuur het, naamlik om die boek te sien as die begin van die Deuteronomistiese Geskiedenis.

\subsection{Die boek Josua as deel van die Heksateug}

Daar is, bloot oppervlakkig gelees, verskillende verbande tussen die boek Josua en die Pentateug. Verskeie kommentatore (vgl bv Hamlin 1983:xii) het al daarop gewys dat die landsbelofte aan Abram by Sigem gemaak word (Gen 12:6, 7), en dat die verowering en verdeling van die land in die boek Josua afgesluit word met 'n byeenkoms en verbondsluiting by Sigem (Jos 24:1-28). Afgesien van die landsbelofte as 'n tematiese verbinding, is die figuur van Josua ook 'n samebindende element tussen die boek Josua en die Pentateug. Dit geskied veral deur die wyse waarop die figuur van Josua op dié van Moses gemodelleer word.

Volgens hierdie benadering vorm die boek Josua die slot van die verhaal waarin die landsbelofte aan die aartsvaders vervul word. Die bronne wat in die Pentateug voorkom (J, E \& P) word hiervolgens in die boek Josua voortgesit (vgl Curtis 1994:1517). Die histories-kritiese metode van ondersoek verskaf die argumente vir die benadering tot die boek Josua as deel van die Heksateug (vgl Deist 1987:15-35). Soos blyk uit Noort se ondersoek het die navorsing oor die boek Josua aan die einde van die negentiende eeu en begin van die twintigste eeu veral op hierdie verband gekonsentreer. Die navorsing van onder andere De Wette, Ewald, Bleek, Knobel, Colenso, Kuenen, Wellhausen, Dillmann, Smend, Steuernagel, Eissfeldt en Rudolph (Noort 1998a:59-87) is 
almal voorbeelde van 'n benadering wat die boek Josua as deel van die Heksateug beskou het.

Die histories-kritiese ondersoek van die boek Josua het 'n groot bydrae gelewer tot die verstaan van die ontstaansproses van die boek as deel van die Heksateug. In die ondersoek het die verstaan van die boek as 'n literêre eenheid egter in die slag gebly. Die boek in sy finale vorm het weinig aandag gekry. Die feit dat daar nie tot eenstemmigheid oor die verdeling van die boek in die verskillende bronne gekom kon word nie, het uiteindelik van die histories-kritiese benadering 'n onbevredigende metode gemaak om die boek Josua mee te verklaar. Von Rad (1938) het 'n poging aangewend om die navorsing oor die Heksateug uit hierdie doodloopstraat te kry. Hy het aangetoon dat die Jahwis daarvoor verantwoordelik was om die Sinai-tradisie by die tradisie oor die inname van die land te laat aansluit. Daarmee saam het die Jahwis die aartsvaderverhale uitgebrei en hierdie nuwe literêre eenheid van 'n proloog in die vorm van die oergeskiedenis voorsien. Hierdie werk van die Jahwis kan in die "freigeistigen" era van Salomo gedateer word. Volgens Auld (1980:3) het Von Rad met hierdie hipotese daarin geslaag om nuwe momentum an die bestudering van die Heksateug te gee wat van fundamentele belang was vir die verhouding tussen die boek Josua en die Pentateug.

\subsection{Die boek Josua as deel van die Deuteronomistiese Geskiedenis}

In 1943 verskyn Noth se Uberlieferungsgeschichtliche Studien wat as 'n waterskeiding in die Ou-Testamentiese navorsing beskou kan word. Hierin stel Noth die hipotese dat die boeke Deuteronomium tot 2 Konings (Rut uitgesluit) 'n literêre eenheid vorm wat deur 'n redakteur (Sammler) saamgestel is om die sogenaamde Deuteronomistiese Geskiedenis te vorm. Die gedagte dat die boek Josua deel is van die Deuteronomistiese Geskiedenis het gaandeweg al hoe meer veld gewen. Soggin (1972:3, 4) gaan byvoorbeeld in die inleiding van sy kommentaar op Josua volledig van die standpunt uit dat die boek deel is van die Deuteronomistiese Geskiedenis. Ook Polzin (1980) is van mening dat die boek Josua volledig deel is van die Deuteronomistiese Geskiedenis wat volgens hom 'n "united literary work" is. Noth se teorie is aangepas en verwerk in die navorsing van Nelson (1981b) en Mayes (1983). Eersgenoemde het aangetoon dat Noth se teorie van 'n enkele

outeur vir die Deuteronomistiese Geskiedenis onwaarskynlik is en dat daar ten minste 
twee redaksies van die Deuteronomistiese Geskiedenis was. Die belangrikste redaksionele werk aan die boek het plaasgevind in die tyd van koning Josia en is later aangevul deur 'n redakteur tydens die ballingskap (Nelson 1981b:120-21). Mayes het weer aangetoon hoe hierdie twee redaksies in spesifieke boeke, soos onder andere Josua, neerslag gevind het. Alhoewel al die aspekte van Noth se teorie nie meer algemeen aanvaar word nie, word sy hipotese van 'n Deuteronomistiese Geskiedenis in sekere kringe steeds as gesaghebbend beskou. In hierdie verband het die gedagte dat die boek Josua 'n propagandadokument vir die Deuteronomistiese hervormings van koning Josia is, heelwat aandag gekry (Nelson 1981a:540).

Uit die navorsing wat van die standpunt uitgaan dat die boek Josua deel is van die Deuteronomistiese Geskiedenis, is daar oorvloedige bewyse dat daar wel 'n verband tussen die boek Josua en die boek Deuteronomium, sowel as die res van die sogenaamde Deuteronomistiese Geskiedenis, bestaan. Hierdie verband word nie ontken nie. Dit is egter 'n vraag of die Deuteronomistiese Geskiedenis die enigste agtergrond is waarteen die boek Josua verstaan moet word. Daar kan 'n aantal argumente aangevoer word wat daarop dui dat dit beslis nie die geval is nie.

In die eerste plek vra Noth self die belangrike vraag: As die boek Josua die begin van die Deuteronomistiese Geskiedenis is en nie deel is van die Pentateug nie, wat het dan van die slot van die Pentateugverhaal geword? Dit is tog net logies om te verwag dat die verhaal sou eindig met 'n weergawe van die inname van die land.

Die feit dat die boek Josua juis in sommige gevalle verskil van die boek Deuteronomium is ' $n$ tweede rede waarom eersgenoemde nie net as deel van die Deuteronomistiese Geskiedenis beskou behoort te word nie. Die stiptelike onderhouding van die wet en gevolglike sukses (Jos 1:7,8) is kenmerkend van Deuteronomium. Dit word in die boek Josua gedemonstreer deur die Akan-episode (Jos 7:1-8:29). Die teenoorgestelde kom egter ook in die boek Josua voor, naamlik dat as die wet nie tot op die letter toegepas word nie, dit tog deur sukses gevolg kan word. Dit blyk veral uit die ooreenkomste wat met Ragab (Jos 2:1-21; 6:22-25) en die Gibeoniete (Jos 9:1-27) gesluit word. In Deuteronomium 7:2 word die opdrag gegee om die nasies as 'n banoffer aan JHWH om die lewe te bring; daar word 'n verbod geplaas daarop om hulle jammer te kry en 'n verbond met hulle te sluit. Ten spyte van die ooreenkoms met Ragab en die feit dat 
haar en haar familie se lewens gespaar word, word Jerigo tog suksesvol ingeneem. In Deut 20:15-18 word die toegewing gemaak dat daar vrede gesluit kan word deur die Israeliete met stede wat baie ver van hulle af is, maar dat almal in die stede wat deur JHWH aan hulle as besitting gegee word, as 'n banoffer aan JHWH om die lewe gebring moet word. Ten spyte daarvan dat dit aan die lig kom dat die Gibeoniete nie ver van die Israeliete af woon nie en dat die ooreenkoms met hulle gehandhaaf word en hulle lewens gespaar word, behaal Josua groot oorwinnings en sukses met die inname van die land (Jos 10:1-12:24). Dit wil dus voorkom asof die boek Josua in sommige gevalle 'n bepaalde nuansering van die Deuteronomistiese eis van stiptelike onderhouding van die wet, aanbied.

'n Verdere rede waarom die boek Josua nie bloot as 'n deel van die Deuteronomistiese Geskiedenis beskou behoort te word nie, het te doen met die plek wat Jerusalem as sentrale heiligdom in die Deuteronomistiese Geskiedenis inneem. Nicholson (1963) het reeds aangetoon dat die aanbidding van JHWH by een sentrale heiligdom een van die fundamentele eise in die boek Deuteronomium is. Daar word algemeen aanvaar dat dié heiligdom Jerusalem is. Halpern (1981) het ook die belangrike rol van die sentralisering van die kultus in die boek Deuteronomium aangetoon. Dit is opmerklik dat daar geen direkte spore van so 'n eis in die boek Josua gevind kan word nie. Polzin (1980:111) se argument dat Gilgal in die boek Josua moontlik 'n bedekte verwysing na Jerusalem is, kom geforseerd voor. Dit verklaar ook nie waarom daar in die boek Josua klem gelê word op ander heiligdomme soos Silo, Ebal en Sigem nie. Op die oppervlak speel Jerusalem geen rol in die boek Josua nie. Jerusalem word trouens in 'n negatiewe sin vermeld (Koorevaar 1990:260) as een van die stede wat verower is (Jos 12:10) nadat die koning 'n opstand teen Josua georganiseer het (Jos 10:1-5).

Op grond van al bogenoemde redes lyk dit of die Deuteronomistiese Geskiedenis nie die enigste raamwerk is waarbinne die boek Josua verstaan kan word nie. Alhoewel die boek Josua in vele opsigte die hand van die Deuteronomistiese redakteurs verraai, wil dit tog voorkom of die boek ook deel was van 'n ander proses van literêre ontwikkeling. 


\subsection{Die boek Josua as produk van 'n literêre proses}

Volgens Hamlin (1983:xxii) het die verhaal van Josua oor 'n lang tydperk ontwikkel en is dit in verskillende situasies hervertel. Hiervolgens sou 'n verteller uit die noorde van Israel in ongeveer $900 \mathrm{vC}$ sekere tradisies aangaande Gilgal, Jerigo, Ai en Gibeon versamel het met die bedoeling om aan te toon dat Josua die Efraimiet en opvolger van Moses (en nie Dawid nie) die een was wat Israel ingelei het in die land wat deur God belowe is. Daarna sou ' $\mathrm{n}$ lid van die Deuteronomistiese hervormingsbeweging tussen 700 en 587 vC 'n nuwe weergawe van die Josua-verhaal die lig laat sien het. Sy doel sou wees om Josua as rolmodel vir die jong koning Josia voor te hou wat betref sy godsdienstige hervormings en militêre uitbreidings. Ten slotte word die Josua-verhaal deur 'n profeet (soortgelyk aan Jesaja 40-55) tussen 587 en 538 vC aangepas om te dien as ' $n$ inspirasie vir baie Israeliete wat droom van 'n terugkeer uit die ballingskap na hulle vaderland.

Fritz (1994:3, 4) meen dat die boek Josua se finale vorm eers teen die vierde eeu vC (dws aan die einde van die Persiese ryk) beslag gekry het. Dit sou die resultaat wees van 'n Grundschrift wat twee redaksies ondergaan het. Die eerste was 'n Deuteronomistiese redaktor wat die geskrif binne die raamwerk van die Deuteronomistiese teologie geredigeer het. Die tweede was 'n na-priesterlike redaksie wat alleen op kultiese instellings gekonsentreer het. Laasgenoemde was volgens hom dan verantwoordelik vir die finale Hebreeuse vorm van die boek Josua.

Die benadering om die boek Josua te sien as die resultaat van 'n literêre proses van ontwikkeling bied die moontlikheid om die boek in sy finale vorm te ondersoek. Dit bevry die ondersoeker van die versoeking om die teks in onsamehangende deeltjies te versnipper asook die gevaar om die boek by voorbaat vanuit die bepaalde raamwerk van 'n groter korpus literatuur te verklaar. Dit bied ook die moontlikheid om die verband tussen die boek in sy finale vorm en ander literatuur in die Ou Testament aan te toon.

\section{IDEALISERING IN DIE BOEK JOSUA}

\subsection{Josua 1:1-9 as 'n programmatiese inleiding tot die boek}

In JHWH se openingstoespraak (Jos 1:1-9) word die belangrikste tema's in die verhaal aan die orde gestel (Polzin 1980:74). Dit is die langste enkele toespraak van JHWH in 
die hele verhaal van Josua. Die ander kere wat JHWH aan die word, kom is dit by wyse van kort opdragte en bevele aan Josua. Daar bestaan 'n groot mate van eenstemmigheid onder navorsers dat Jos 1:1-9 'n besondere funksie vervul. Polzin (1980:74) beskou dit as 'n paradigmatiese illustrasie van die hele Deuteronomistiese Geskiedenis se tema. Gottwald (1985:241) noem dit 'n "programmatic text". Spronk (1994:25) het aangetoon dat daar in Jos 1:1-9 'n ideaal geskets word wat haas onmoontlik lyk, naamlik die ideaal van "één God, één volk, één land, één leider". Hy wys daarop dat die eerste hoofstuk ook op ander maniere as 'n inleiding tot die res van die verhaal beskou kan word. Die volgende elemente kan in hierdie rede van JHWH onderskei word:

- Leierskap: Die Israeliete het 'n behoefte aan 'n nuwe leier want Moses, die עבד is dood. Josua word deur JHWH aangestel as Moses se opvolger met die opdrag om die land in besit te neem (Jos 1:2, 6). Die manier waarop Josua daarin slaag om by Moses as die ideale leier oor te neem is een van die deurlopende tema's in die boek.

- Die volk: God noem die volk בל־יהעם en בני ישראל (Jos 1:2). Die vraag na die identiteit van Israel is 'n belangrike tema in die boek Josua. Die klem val hier op die eenheid binne die volk van JHWH.

- Die land: Die land word hier as 'n eenheid gesien. Josua word aangestel om hierdie מהמדבר... ועד־הנהר הגדול מה מיד (Jos 1:4). Klem word gelê op die feit dat JHWH oor die land beskik (Jos 1:2, 6, 11). Die land is JHWH se belofte aan die aartsvaders. Die volk het uit hulle eie geen reg op die land nie. Dit kom hulle alleen toe op grond van JHWH se belofte. Die gedagte word telkens uitgedruk dat JHWH die land vir hulle gee (נתאן). Moses geld as 'n gesagsfiguur ten opsigte van die landsbelofte. Die gebied wat Josua in besit moet neem, word in Jos 1:3 genoem בל־מקום אשר תדרך. Die grense van die land word hier baie wyd en idealisties voorgestel (Jos 1:4). Die ideaal is dat die hele gebied Israel se woongebied (גבולכם) sal wees. 
- Die ander nasies: Wat die nasies betref teen wie Josua sal moet veg in die uitvoering van sy opdrag om die land in besit te neem, word dit in die vooruitsig gestel dat, solank as wat hy lewe, niemand teen hom staande sal kan bly nie: לא־ייתיצב לפניך כל ימי חייך (Jos 1:5). Die ideaal is dus dat al hierdie nasies onderwerp sal word.

- Die onderhouding van die wet: Die ideaal is dat die hele wet (כל התורה) nagekom sal word (Jos 1:7). Moses geld ook as 'n gesagsfiguur ten opsigte van die wet. Absolute gehoorsaamheid aan die wet van Moses is 'n vereiste vir sukses (Jos 1:8).

\subsection{Die verband tussen Josua 1:1-9 en 23:1-16}

Die byeenkoms in Jos 23:1-16 kom ooreen met die wetslesing op Ebalberg (Jos 8:30-34) waar die hele Israel (כל-ישראל) teenwoordig is, naamlik die leiers, die hoofde, die regters en die ampsdraers (Jos 23:2). Daar is egter ook opvallende ooreenkomste met Jos 1:1-9. Josua se "summary speech" in Jos 23 word ook deur Gottwald (1985:241) saam met Jos 1:1-9 as 'n "programmatic text" beskou. Die volgende aspekte is van belang:

- JHWH het die oorlog vir die Israeliete gevoer. Niemand kon teen hulle staande bly nie (Jos 1:5 en 23:9, 10).

- Die land is nog nie volledig ingeneem nie. Dit sal nog in die toekoms realiseer soos JHWH belowe het (Jos 1:3, 6 en 23:4, 5).

- Die grense van die land is nie so wyd soos in Jos 1:4 nie. Die Jordaanrivier word in Jos 23:4 as die oostelike grens aangedui.

- Die volk moet sterk staan in die uitvoering van die wet, nie links of regs afwyk nie en nie ander gode dien nie (Jos 1:7, 8 en 23:6-8). 
- Indien hulle egter afvallig raak deur hulle aan die ander nasies te verbind, met hulle te trou of te vermeng, sal hulle swaar kry en uiteindelik verdwyn uit die land wat JHWH aan hulle gee (Jos 1:2 en 23:13, 15, 16).

- Die feit dat al JHWH se beloftes aan hulle vervul is, impliseer ook dat al die rampe hulle sal tref indien hulle nie die verbondverpligtinge nakom nie (Jos 1:7, 8; 23:12v).

Dat Jos 1:1-9 'n idealistiese voorstelling is, word aangedui deur die herhaalde gebruik van die woord כל Die woord kom agt keer in die gedeelte voor. Hiervolgens het die realisering van JHWH se beloftes reeds volledig aangebreek. Daar is egter ook 'n ander stem hoorbaar in die boek Josua. Dit is die stem wat die leser voortdurend daaraan herinner dat al hierdie ideale in werklikheid nog nie gerealiseer het nie. Dit kom tot uitdrukking in Jos 23:1-16. Hierdie gedeelte kan dus eintlik gesien word as kommentaar op, of 'n interpretasie van, Jos 1:1-9. Die doel is om an te dui dat JHWH alles wat Hy belowe het, nakom. In sekere gebiede is die nasies uitgeroei en die wat nog oor is se gebiede is reeds aan Israel toegeken, alhoewel die nasies wat daar woon nog deur JHWH verdryf sal word. Die finale realisering van JHWH se belofte lê dus nog in die toekoms.

\subsection{Teologies-ideologiese fasette in die boek Josua}

\subsubsection{Die land as 'n gawe van JHWH}

Die gedagte dat JHWH in beheer is en dat Hy sy belofte vervul om 'n land aan sy volk te gee, kom sterk in die Josua-verhaal na vore. Dit is JHWH wat die land aan die Israeliete gee (נתן) en wat die oorlog namens hulle voer. In die proses gebruik JHWH mense soos Josua en die Levitiese priesters om die land in besit te neem en dit onder al die stamme van Israel te verdeel. In die verhaal is Josua die instrument waardeur JHWH werk. JHWH gee die opdragte en Josua voer dit stiptelik uit. JHWH regeer sy volk deur te praat, dit wil sê deur sy woord. Josua vervul die rol van 'n profeet deurdat hy as 'n tussenganger optree tussen JHWH en die volk. Hy dra die woord van JHWH aan die volk oor en sien toe dat dit uitgevoer word. 


\subsubsection{Die עבד יהוה}

Josua verteenwoordig in die vertelling die ideale leier van JHWH se volk. Hy volg in die voetspore van Moses, die עבד ידהוה. Hy beywer hom vir die stiptelike onderhouding van die wet sowel as die eenheid van JHWH se volk, maar hy betoon terselfdertyd 'n besondere besorgdheid teenoor buitestaanders. Hy is nie uit die stam van Juda afkomstig nie en word ook nie aan een bepaalde kultiese sentrum verbind nie. Hy bied ook aan die Levitiese priesters die ruimte om 'n leidende rol te speel. Moses se dood het 'n leemte en 'n behoefte aan 'n nuwe leier gelaat. Die verhaal in die boek Josua handel in 'n groot mate oor die wyse waarop Josua daarin slaag om by Moses as leier van die Israeliete, dit wil sê as die עבד י יהוה oor te neem.

\subsubsection{Die kultus}

Daar is in die boek Josua nie sprake van een sentrale heiligdom nie. Die inname van die land word as 'n kultiese prosessie voorgestel waarvolgens die hele land as 'n heiligdom vir JHWH verower word. Daar is wel 'n tendens van desentralisasie van die kultus in die boek Josua waarneembaar. Verskillende kultiese plekke verkry prominensie in die boek. Die feit dat Jerusalem as kultiese sentrum afwesig is en die boek afsluit met 'n byeenkoms by Sigem, dui daarop dat Sigem waarskynlik die plek van aanbidding is wat by die verteller voorkeur geniet. Daarby word die priesters spesifiek die "Levitiese priesters" in die boek genoem. Hulle speel 'n prominente rol in die kultiese prosessies tydens die inname van die land. Priesters is ook verantwoordelik vir die regverdige verdeling van die land en om die eenheid van die volk te herstel wanneer daar 'n skeuring op grond van 'n godsdienstige verskil dreig.

\subsubsection{Die volk van JHWH}

Die eenheid van die volk geniet 'n hoë prioriteit in die boek Josua. Die ideaal is om al die stamme as die een volk van JHWH te verenig. Die werklikheid getuig egter van verdeeldheid onder die volk op grond van 'n kultiese aangeleentheid wat handel oor die plek waar offers gebring moet word. Uiteindelik vind daar versoening tussen die twee groepe plaas deur die bemiddeling van 'n priester. 
Die eenheid van die volk word verder gedemonstreer deur die byeenkoms by Sigem. Die hele volk is daar bymekaar. Die eenheid van die volk kom daarin tot uitdrukking dat die hele volk kies om JHWH te dien. Dit is dus nie noodwendig 'n geografiese eenheid nie, maar wel 'n religieuse eenheid van die dienaars van JHWH. Die volk word onder leiding van die עבד יהוה almal verenig tot ware dienaars van JHWH.

\subsubsection{Onderhouding van die wet en die verhouding met ander nasies}

Daar word in die boek Josua hoë waarde geheg aan die stiptelike onderhouding van die wet. Dit mag egter nie in die pad staan daarvan om met menslikheid en verantwoordelikheid teenoor ander nasies op te tree nie. Net soos wat JHWH sy belofte nakom wat Hy met 'n eed aan die voorvaders van die volk gemaak het, naamlik om die land aan hulle te gee, só moet die Israeliete nou die ooreenkomste wat hulle met 'n eed aan die ander nasies gemaak het, nakom. Daar moet met menslikheid opgetree word teenoor buitestaanders. Hulle moet eerder in die gemeenskap van die volk van JHWH opgeneem word. Die ander nasies hoef nie noodwendig deur militêre optrede verdryf te word nie. Hulle kan, deur aan hulle goed te doen, ook deel word van die volk wat JHWH dien.

\section{OOREENKOMSTE TUSSEN TRITO-JESAJA EN DIE BOEK JOSUA}

Die teologie van Trito-Jesaja vertoon duidelike raakpunte met die teologie van die boek Josua (vgl Lindeque 2001:66-69). Die volgende aspekte is in dié verband van belang:

\subsection{Verset teen die tempel en die priesters}

Volgens Trito-Jesaja kom dié wat oor die volk moet waak, dit wil sê die priesters, nie hulle verantwoordelikheid na nie (Jes 56:9-12). Die priesters se ontrouheid en die temple waar hulle diens doen, word in Jesaja 57:3-9 vergelyk met die bed van 'n prostituut op 'n hoë berg waarop daar onsedelikheid gepleeg word (Hanson 1989:198-200). Hulle word opgeroep om nader te kom (קרבו) om die aanklag teen hulle en hulle vonnis aan te hoor. Hulle is gebore uit hoerery (ותזנה). Die berg waar hierdie onsedelikheid, naamlik die bring van offers vir ander gode plaasvind, is die teenpool van JHWH se heilige berg (Jes 
56:7). Die prostituut het haar bed wyd gemaak (הרחבת משכבך) om al die nieJahwistiese elemente te akkommodeer (Hanson 1989:200), en het haarself verbind deur 'n ooreenkoms te sluit (ותכרת-לד) met hulle saam met wie sy graag slaap (אהבת משכבם, vgl Jes 56:8). Hierdie gedeelte vertoon heelwat semantiese ooreenkomste met Jos 2:1-24. Volgens laasgenoemde vind die eerste kontak van die Israeliete met die bevolking van Kanaän aan huis van 'n prostituut plaas רחב (Jos 2:1), wat onder andere vertaal kan word met "wyd". Seksuele omgang tussen die verkenners en Ragab word verder gesuggereer deur die gebruik van וישכבו־שמה (Jos 2:1). Ragab gaan, soos die prostituut in Jes 57:8, ook 'n ooreenkoms aan met hulle wat by haar geslaap het (Jos 2:12-14).

JHWH het volgens Trito-Jesaja nie 'n tempel nodig nie want Hy is die Skepper van alles wat bestaan (Jes 66:1-2a). Dit gaan vir Trito-Jesaja egter nie oor die feit dát daar 'n huis vir JHWH gebou word nie, maar oor wié dit bou en wat die aard van die huis sal wees (Beuken 1989:100,1). Die uitdrukking איזיז (Jes 66:1) kan ook met die vraagwoord "waar?" vertaal word. Dit kan as 'n retoriese vraag beskou word en sou dan impliseer dat JHWH op enige plek (מקום) kan woon aangesien Hy alles gemaak het en dat alles (בל) deur Hom ontstaan het (Jes 66:2). Afgesien van die vraag waar of van welke aard JHWH se huis moet wees, gaan dit hier in beginsel ook oor 'n ander kontrovers in verband met die huis van JHWH. Die probleem wat Trito-Jesaja het in verband met die huis van JHWH, is dat daar offers vir JHWH gebring word en terselfdertyd onrein offers, selfs mense, vir die afgode geoffer word (Jes 66:3). Die huis van JHWH het dus 'n plek geword waar afgode ook gedien word. Die onderliggende verset teen die tempel gaan dus oor die aard van die tempeldiens wat vermeng word met afgodsdiens, terwyl JHWH in sy almag nie 'n behoefte het aan offers nie maar wel dat daar ag geslaan word op die mens in nood (Jes 66:2b, 3). Die negatiewe houding teenoor die tempel word in Trito-Jesaja uitgedruk deur opmerkings dat dit oorbodig is (Jes 66:12a), die offers daar onrein is (Jes 66:3) en dat die tempel vol van JHWH se vyande is (Jes 66:6).

'n Negatiewe houding teenoor die tempel word in die boek Josua weerspieël deur die feit dat Jerusalem, offers en die tabernakel (as voorloper vir die tempel) so 
onderbeklemtoon word in die boek Josua, dat dit bykans geen rol speel nie. Josua tree by verskillende heiligdomme soos Gilgal, Ebal, Silo en Sigem op. Die enigste plek waar Josua ' $\mathrm{n}$ offer bring, is op Ebalberg (Jos 8:30,31). Wanneer Jerusalem genoem word is dit in verband met die vyandige gesindheid van die koning van Jerusalem teenoor die volk van JHWH (Jos 10:3). Die kultiese rituele wat wel in Josua genoem word, naamlik die besnydenis (Jos 5:2-9) en die viering van die Paasfees (Jos 5:10-12), hoef nie by 'n tempel plaas te vind nie.

Die negatiwiteit teenoor die tempel in Trito-Jesaja versterk die moontlikheid om אייזזה מקום מנוחתי (Jes 66:1) te vertaal as: "[W]aar sal die plek wees waar Ek woon?" Die geïmpliseerde antwoord is dat JHWH op enige plek kan woon. Dit strook dan ook met כל מקום Jos 1:3 en die ideaal in die boek Josua van die inname van die hele land as 'n heiligdom vir JHWH. Die kollektiewe uitdrukking כל מקום word soms geassosieër met die legitimiteit van 'n bepaalde altaar en nie dié van 'n gebou soos die tempel nie. Die uitrdukking het die betekenis "oral". By enige altaar waar JHWH gedien word, daar is JHWH teenwoordig. Dit is nie die מקום wat die kultus legitimeer nie, maar wel die kultus wat die מקום legitimeer (Botterweck 1997:539-540).

JHWH straf sy vyande wat volgens Jes 66:6 in die tempel (היכל) is. Hulle word egter terselfdertyd die lesers van Trito-Jesaja se broers (אחיכם) genoem (Jes 66:5). Daaruit kan afgelei word dat die konflik oor die tempel 'n interne konflik binne die geloofsgemeenskap is. Beuken (1989:106) wys daarop dat hierdie konflik al verstaan is teen die agtergrond van verskillende historiese situasies. Dit is al vertolk as deel van die konflik tussen die Samaritane en die tempelgemeente van Jerusalem in die tyd van Esra, of as deel van die spanning tussen die agtergeblewe sinkretistiese landsbevolking en die terugkerende ballinge. Dit is ook al herlei na die stryd tussen, aan die een kant 'n profetiese groep wat die herstel van die erediens en die eskatologiese ingryping van God verwag het, en aan die ander kant 'n hiërokratiese groep wat die herstel van die tempel en die kultus as die verwerkliking van die heil beskou het. Die "broers" (Jes 66:5) sou dan laasgenoemde priesterlike kring, wat die tempelberg en die amptelike kultus onder hulle beheer gehad het, verteenwoordig, terwyl Trito-Jesaja se gehoor dan die profetiese groepering wat van alles uitgesluit is, verteenwoordig. 
Die kontrovers rondom die gedenkaltaar in Jos 22:1-34 is soortgelyk aan dié rondom die tempel in Trito-Jesaja. In Trito-Jesaja is daar twee groepe naamlik die dienaars van JHWH en hulle vyande in die tempel (Jes 66:14). In Jos 22 is daar ook sprake van twee groepe naamlik die stamme aan die ooste- en dié aan die westekant van die Jordaanrivier. Die westelike stamme word ook die oostelike stamme se "broers" genoem (Jos 22:3, 4; vgl Jes 66:5). Daar bestaan egter spanning tussen die twee groepe oor 'n kulties-religieuse aangeleentheid naamlik die "bou" (בנה) van die gedenkaltaar ( vgl Jos 22:10 en Jes 66:1). Die oostelike stamme se vrees is dat hulle in die toekoms deur hulle "broers" aan die westekant van die Jordaan van die diens van JHWH uitgesluit sal word en dat daar vir hulle gesê sal word dat hulle geen deel (אין־לכם חלק) het in JHWH nie (Jos 22:25, 27; vgl Jes 61:7 waar belowe word dat hulle oor hulle deel [חלקם] sal jubel).

\subsection{Alle mense sal toegang hê tot die volk van JHWH}

Volgens Trito-Jesaja is JHWH se nuwe verbond met sy volk daarop gerig om ook ander nasies te bereik. Mense wat voorheen as onrein beskou is, soos nie-Israeliete en ontmandes, sal 'n ereplek in JHWH se huis kry (Jes 56:3-5). Nie-Israeliete wat hulle onderwerp aan JHWH se bepalings sal ook deel hê aan die kultus, want JHWH se huis sal 'n huis van gebed vir alle volke wees (לכל־העמים, Jes 56:6, 7). Hiermee plaas TritoJesaja die gevalle van vreemdelinge en ontmandes wat tot die gemeente van God toetree, in die perspektief van die wêreldwye heil (Beuken 1989:34). Wat vir die doel van hierdie studie belangrik is, is die feit dat die ontmandes kies (בחר) om JHWH te dien en volgens sy verbond te lewe (Jes 56:4), en dat die nie-Israeliete by die volk van JHWH aansluit om Hom te dien (לשרתו) en om sy dienaars te wees (לעבדים) en om ook volgens sy verbond te lewe (Jes 56:6). Volgens Trito-Jesaja sal nasies (גוים) na die lig van Jerusalem toe kom en mense sal van ver (מרחוק) af kom om hulle by die volk van JHWH aan te sluit (Jes 60:3, 4, 8-10).

Die hele saak van die regte gesindheid teenoor vreemdelinge wat vir Trito-Jesaja so belangrik is, kom in die boek Josua na vore in die berigte oor Ragab en haar familie (Jos 2 en 6) en die Gibeoniete (Jos 9) wie se lewens gespaar word op grond van die 
ooreenkomste wat met hulle aangegaan is. In hierdie opsig dien die berig oor Ragab as 'n illustrasie van wat die verteller in die boek Josua beskou as die regte gesindheid teenoor vreemdelinge. Volgens Mitchell (1993:190) is die berigte oor Ragab en die Gibeoniete die sleutel tot die verstaan van die Josua-verhaal. Ragab en die Gibeoniete beeld die gewone vreemdelinge wat in JHWH se diens staan, uit. Ragab is 'n instrument van JHWH deurdat sy die verkenners wegsteek en help om te ontsnap. Sodoende dra sy by tot die inname van die land. Die Gibeoniete mislei Josua deur voor te gee dat hulle van 'n ver land af kom. Dit stem ooreen met die gedagte in Trito-Jesaja dat mense van ver af (מרחוק) sal kom om hulle by die volk van JHWH aan te sluit (vgl Jos 9:6, 9 en Jes 60:4). Josua sluit dan 'n ooreenkoms met die Gibeoniete en stel hulle aan om dwangarbeid te verrig en om selfs by die altaar van JHWH diens te doen (vgl Jos 9:27 en Jes 60:7; 66:21). Ragab sowel as die Gibeoniete getuig van die mag en die roem van JHWH (vgl Jos 2:9-11; 9:9, 10 en Jes 66:18, 19).

Koole (1995:49) het reeds aangetoon dat die verwysings na nie-Israeliete in TritoJesaja (bv Jes 56:3) nie verwar moet word met die "vreemdeling" (גר) wat 'n beskermde regsposisie ingeneem het en wat aan die offerdiens kon deelneem nie. Buitestaanders verwys in Trito-Jesaja na die burgers van die volke wat Israel se vyande was. Hulle was

heidene. Polities en religieus was daar tussen hulle en Israel 'n groot teenstelling. Hierdie buitestaanders het volgens Trito-Jesaja in die vrees geleef dat hulle van JHWH se volk geïsoleer sou word. Dieselfde kan ook gesê word van die buitestaanders soos Ragab en die Gibeoniete in die boek Josua.

Tog is daar ook ' $n$ verskil tussen Trito-Jesaja se siening ten opsigte van buitestaanders en dié van die boek Josua. By eersgenoemde is daar sprake van 'n algemene universalisme, terwyl die goedgesindheid teenoor en die insluiting van buitestaanders in die diens van JHWH in die boek Josua meer beperk word. Alhoewel Trito-Jesaja en die boek Josua nie in alle opsigte hierin ooreenkom nie, is daar tog opvallende ooreenkomste.

\subsection{Medemenslikheid is belangriker as rituele handelinge}

Die vasdae het, volgens Trito-Jesaja, geen betekenis as daar nie na die nood van ander omgesien word nie. Daar moet in hulle basiese behoeftes soos brood, blyplek en klere 
voorsien word (Jes 58:7). JHWH kom dié te hulp wat doen wat reg is (Jes 64:5). Vir JHWH is die nood van mense, berou oor sonde en gehoorsaamheid aan sy woord belangriker as die offers wat in elk geval vermeng word met die offers aan afgode (Jes $66: 2 b, 3)$.

Josua word uitgebeeld as iemand wat omgee vir die nood van ander mense en sy woord teenoor hulle hou. Hy laat Ragab en haar familie nie aan hulle lot oor wanneer Jerigo ingeneem word nie. Hy behandel die Gibeoniete goed (Jos 9:15) wanneer hy hulle droë brood en verslete klere sien, en beskerm hulle (Jos 9:26). Hy spaar Ragab en die Gibeoniete se lewens en laat hulle toe om tussen die Israeliete te woon. Daarmee voorsien hy in hulle basiese behoeftes van brood, kleding en woonplek (vgl Jes 58:7). Oorwinning oor die ander nasies is dus nie noodwendig 'n militêre oorwinning nie. Dit kan ook beteken om aan mense goed te doen en hulle op te neem in die diens van JHWH.

\subsection{Die heilstyd sal eers in die toekoms realiseer}

Die voorwaarde vir die aanbreek van die heilstyd is, volgens Trito-Jesaja, dat daar reg en geregtigheid moet geskied (Jes 56:1). Die heilstyd het nog nie aangebreek nie want al die verstrooides van Israel is nog nie bymekaargemaak nie (Jes 56:8). Dié wat by JHWH skuil, sal die land in besit neem (נחל-ארץ, vgl Jes 57:13; 60:21) en JHWH se heilige berg as eiendom ontvang (ויירש, Jes 57:13). Wanneer daar omgesien word na die verdruktes en dié in nood (Jes 58:9, 10) en wanneer die sabbat reg gevier word (Jes 58:13, 14), sal JHWH weer sy volk die land in besit laat neem (Jes 58:14). Dan sal Hy hulle laat eet (והאכלתיך) van die opbrengs van die land (Jes 58:14). Dit sal 'n tydperk van herstel wees waartydens die puinhope en afgebreekte mure herbou sal word (Jes 58:12; 61:4). Die heilstyd het vanweë die volk se sondes nog nie aangebreek nie (Jes 59:2, 12). Eerlikheid en betroubaarheid ontbreek (Jes 59:4, 14, 15). Maar wanneer die heilstyd aanbreek sal die Naam van JHWH van oos tot wes geëer word en JHWH sal alle teenstanders verdryf (Jes 59:19). Die skatte van ander nasies sal in Israel se besit kom (Jes 60:5-7, 11; 61:6). Die wat voorheen verdruk was in die volk van JHWH sal priesters en "dienaars van ons God".(משרתי אלהינו) genoem word (Jes 61:6). JHWH sal aan sy volk gee wat Hy beloof het, en 'n ewige verbond (ברית עולם) met hulle sluit (Jes 
61:8). Hulle sal lof ontvang oor hulle deel (חלקם) en baie meer as voorheen besit (ירשי", Jes 61:7).

Die inname van die land in die boek Josua kan met die heilstyd wat volgens TritoJesaja in die toekoms gaan aanbreek, in verband gebring word. In Jos 1:4 word die gebied wat Israel gaan inneem geïdealiseer as 'n gebied wat baie groter is as wat ooit werklik onder Israel se beheer was. Volgens Trito-Jesaja sal hulle ook in die toekoms baie meer besit (ירשי) as voorheen (Jes 61:7). Die ideaal in Josua is dat die Israeliete die hele gebied in besit sal neem en alle ander volke daaruit sal verdryf. Die werklikheid is dat dit nie gebeur het nie (Jos 13:1). Daarom word die verwagting van die volledige vervulling van JHWH se belofte na die toekoms verplaas (Jos 13:6). Dan sal JHWH aan sy volk dit gee (נת5) wat Hy beloof het (vgl Jes 61:8). In die heilstyd sal buitestaanders soos Ragab en die Gibeoniete wat dan nog in die land oorgebly het, egter ook in JHWH se diens staan. Dan sal die Naam van JHWH van die ooste tot in die weste geëer word (vgl Jos 1:4 en Jes 59:19).

\subsection{Die dienaars van JHWH}

In Trito-Jesaja gaan dit oor die vraag na die dienaar (עבדים) van JHWH. Nie-Israeliete word ook dienaars van JHWH genoem (Jes 56:6). Dit word hier saam met die uitdrukking לשרתו gebruik. Laasgenoemde uitdrukking het in die priesterlike oorlewering 'n tegniese term vir kultiese bediening geword. Beuken (1989:30) meen dat dit hier vanweë die eskatologiese strekking van die gedeelte 'n meer algemeen-sakrale betekenis het van beskikbaarheid vir en verbondenheid aan JHWH.

JHWH word gevra om terug te keer (שוב) "ter wille van u dienaars, die stamme van u erfdeel” (שבטי נחלתך, vgl Jes 63:17). Hierdie versoek word tot JHWH gerig in die konteks van 'n versugting na die ou dae, die tyd van Moses toe JHWH wonders vir sy volk gedoen het (Jes 63:11-14), in besonder die wonder van die deurtog deur die see (Jes 63:11-13a), die woestyntog (Jes 63:13b) en die intog (Jes 63:14a). Die verlede word geïdealiseer naamlik dat "dit relaas van de uittocht een buitengewoon creatieve hervertelling is van het oude gebeuren, naar we mogen aannemen in dienst van de hoop op en het gebed om een nieuwe doortocht" (Beuken 1989a:18). Dit was 'n tyd toe JHWH 
vir hulle rus gegee het (תניחנו), dit wil sê die vryheid om hulle, ongestoord deur vyande, in die land te kon vestig (Beuken 1989a:18). Trito-Jesaja spreek die versugting uit dat JHWH weer die wonders van die verlede vir sy volk sal doen.

Die rol van Moses in die boek Josua stem ooreen met die idealisering van die tyd van Moses, die uittog en die woestyntyd in Trito-Jesaja (vgl Jes 63:11-14). In die boek Josua is Moses die rolmodel vir Josua. Daar word telkens in die boek Josua daarna verwys dat JHWH by Josua was, net soos Hy by Moses was (כאשר משה) en dat Josua sy opdragte stiptelik volgens Moses se bepalings uitvoer. Josua se optrede word dikwels as in lyn met dié van Moses beskryf. In Trito-Jesaja is daar die versugting dat JHWH weer soos in die verlede wonders vir sy volk sal verrig (Jes 63:17b-64:4). In die boek Josua word vertel van 'n groot aantal wonderwerke wat plaasvind. Daar is byvoorbeeld die water van die Jordaan wat opdam sodat die volk kan deurtrek (Jos 3:15,16), die mure van Jerigo wat inmekaar val (Jos 6:20), die oorwinning oor Ai (Jos 8:18,26), die haelstene (Jos 10:11) en die son en maan wat stilstaan (Jos 10:12-14).

Hulle wat deur JHWH uitgekies word om aan Hom te behoort, sal volgens TritoJesaja in die toekomstige heilsbedeling bekendstaan as עבדי יהוה. Moses kom in die משרת משה by uitstek, na vore. Josua word aanvanklik עבד יהוה bosua as die genoem (iemand wat priesterlike funksies verrig). In Jes 56:6 word die uitdrukking gebruik vir vreemdelinge en in Jes 61:6 vir die verstote deel van JHWH se volk. Gaandeweg word dit egter duidelik dat Josua net soos Moses ook 'n dienaar van JHWH is (Jos 24:29). In Jos 24:1-28 stel Josua die volk voor 'n keuse (בחרו) om JHWH te dien of die afgode. Hy stel self die voorbeeld deur eerste te kies om JHWH te dien. Die volk beklemtoon dit dat hulle ook kies om JHWH te dien deur dit drie keer te herhaal (Jos 24:18, 21, 24). In Jes 65:11-12 word daar gesê dat die wat teen JHWH en vir die afgode kies (בחרתם) met die dood gestraf sal word, terwyl sy dienaars voorspoed en blydskap sal beleef .

\subsection{Voorlopige gevolgtrekking}

Uit die voorafgaande ondersoek is dit duidelik dat daar talle ooreenkomste tussen die boek Josua en Trito-Jesaja bestaan. Dit sluit ooreenkomste in op die semantiese, 
ideologiese en teologiese vlak. Aangesien daar sekerheid bestaan dat Trito-Jesaja teen 'n na-eksiliese agtergrond verstaan moet word, kan die voorlopige gevolgtrekking gemaak word dat die boek Josua ook tuis hoort in die tyd na die ballingskap.

\section{OOREENKOMSTE TUSSEN VERTELLINGS UIT DIE NA- EKSILIESE TYD EN VERTELLINGS IN DIE BOEK JOSUA}

\subsection{Vertellings oor Serubbabel en Jesua}

Volgens Smith (1987:82) het daar tydens die herbou van die tempel 'n samewerkingsooreenkoms tussen die eksklusiewe groep, wat hoofsaaklik uit die teruggekeerde ballinge bestaan het, en die priesters tot stand gekom. Die plaaslike bevolking is aanvanklik uitgesluit van die herbou van die tempel. Serubbabel, wat deur die Perse aangestel is as goewerneur, was waarskynlik die leier van die eksklusiewe groep. Van hom is daar sekere messiaanse verwagtinge gekoester. Laato (1992:258) toon aan dat die messiaanse verwagtinge van die profete Haggai en Sagaria 1-8, met Serubbabel uit die nageslag van Dawid, verbind kan word. Serubbabel word ook genoem (Hag 2:23). Volgens die ooreenkoms tussen die priesters en die eksklusiewe groep (Smith 1987:82), sou Serubbabel deur die priesters erken word as die politieke leier en verantwoordelikheid aanvaar vir die herbou van die tempel, terwyl die priesters onder leiding van die hoëpriester Jesua deur die eksklusiewe groep as wettig erken sou word. Tekens van so 'n ooreenkoms kan afgelees word uit Sag 6:1-9. Die voorwaarde vir die samewerkingsooreenkoms tussen die priesters en die eksklusiewe groep was dat die priesters die wet, soos dit deur die eksklusiewe groep geïnterpreteer is (dws die Deuteronomistiese wet), nougeset sou toepas. In ruil daarvoor sou die priesters 'n tweede plek in die regering beklee, die vyandige kritiek ten opsigte van die reinheid van die priesters sou gestaak word en die priesters se bouwerk an die tempel sou finansiële ondersteuning kry. Daarby het die moontlikheid bestaan dat nog meer van die eksklusiewe groep wat nog nie uit ballingskap teruggekeer het nie, angemoedig sou word om wel terug te keer en met die bouwerk te help.

Indien bogenoemde rekonstruksie van Smith korrek is, kan die verhaal in die boek Josua met sommige van hierdie gerekonstrueerde gebeure in verband gebring word. Die 
figuur van Josua in die verhaal beeld die ideale עבד יהוה uit. Ottosson (1991) wys op die messiaanse verwagtinge wat deur die figuur van Josua verteenwoordig word (alhoewel hy die boek Josua beskou as 'n Deuteronomistiese propagandadokument vir die hervormings van koning Josia). Josua is volgens Ottosson (1991:263) die prototipe van die ideale Dawidiese koning en leier van Israel. In plaas daarvan om soos Serubbabel buitestaanders uit te sluit van die diens van JHWH en die herbou van die tempel, is die ideale עבד יהוה egter iemand wat besorg is oor buitestaanders en aan hulle die geleentheid bied om JHWH te dien en om selfs in die tempel diens te doen. Hiervan getuig Josua se optrede teenoor Ragab (Jos 6:25) en die Gibeoniete (Jos 9: 15).

In teenstelling met die veronderstelde samewerkingsooreenkoms tussen die eksklusiewe groep en die Sadokitiese priesters, word Josua in die verhaal voorgestel as 'n leier wat nóú met die Levitiese priesters saamwerk. Dit kom in die verhaal na vore deur die samewerking tussen Josua en die priesters tydens die belangrike moment van die deurtog deur die Jordaan (Jos 3:1-4:18). Daar word na die priesters spesifiek as die Levitiese priesters verwys (Jos 3:3). Wanneer die Jordaan as ideologiese grens oorgesteek word, val die kollig op die priesters wat die ark dra (Jos 3:2,6) en deur wie se toedoen die water van die Jordaan afgesny word (Jos 3:13, 15, 18). Die priesters lei die intog in die land in (Jos 4:11). Josua, wat in hierdie hele proses op die agtergrond bly, is egter volledig in beheer van sake. Hy is die een wat die bevele gee en die volk sowel as die priesters reageer daarop (Jos 3:1-4:18). Dieselfde geld ook vir die inname van Jerigo (Jos 6:1-21). Ook hier is daar duidelik sprake van samewerking tussen Josua en die Levitiese priesters. Josua gee aan die priesters hulle opdragte (Jos 6:6, 11, 12). Die priesters neem deel aan die optog om Jerigo (Jos 8, 9, 13). Die priesters is verantwoordelik vir die dra van die verbondsark (Jos 6:6, 12) en om die ramshorings as teken te blaas (Jos 6:4, 16).

Josua werk ook nóú saam met die priester Eleasar wanneer dit kom by die verdeling van die land onder die verskillende stamme aan die westekant van die Jordaanrivier (Jos 14:1). Die krisis van die gedenkaltaar wat die eenheid tussen die oostelike en die westelike stamme bedreig (Jos 22:9-34), word ook deur 'n priester, naamlik Pinehas die seun van Eleasar, hanteer. Josua is opvallend afwesig. Die verteller 
stel hiermee ook die priesters, soos in die geval van die verdeling van die land onder die stamme, in 'n versoenende en akkommoderende rol voor.

Volgens Smith (1987:8) was die verset van die plaaslike bevolking teen Serubbabel en die priesters se onverbiddelike houding jeens hulle betrokkenheid by die bouwerk aan die tempel waarskynlik die rede daarvoor dat Serubbabel skielik van die toneel af verdwyn het, en die tempel toe sonder hom voltooi en ingewy is (Esra 6:13-18). Dit is egter opmerklik dat die Paasfees gevier word net na die inwyding van die tempel (Esra 6:19-22). Die weerstand teen Jerusalem en die tempel kom in die boek Josua na vore in die totale afwesigheid van Jerusalem as kultiese sentrum. Josua tree by verskillende kultiese sentra soos byvoorbeeld Gilgal (Jos 3:19), Ebal (Jos 8:30), Silo (Jos 18;10) en Sigem (Jos 24:1) op. Josua word egter nooit deur enige kultiese handelinge met Jerusalem verbind nie. Die afwesigheid van Jerusalem word juis geaksentueer deur die prominensie van die ander heiligdomme in die boek Josua. Die Paasfees word in die boek Josua net na die intog in die land gevier (Jos 5:10-12). Daarmee verkry die intog in die land in die boek Josua 'n kultiese dimensie. Die intog in die land as 'n kultiese prosessie waarvolgens die hele land as 'n heiligdom van JHWH in besit geneem word, kan beskou word as 'n legitimering van die inklusiewe denkrigting se standpunt teenoor die eksklusiewe denkrigting se aanspraak dat JHWH slegs op een plek, naamlik Jerusalem aanbid kan word.

\subsection{Vertellings oor Esra}

Volgens koning Artasasta se volmag (Esra 7:12-26) kry Esra die opdrag om die silwer en goud van die koning en sy adviseurs as 'n vrywillige gawe aan die God van Israel wat in Jerusalem woon, weg te bring (Esra 7:15). Hy kan ook vrywillige gawes van die volk en die priesters oor die hele provinsie van Babel bymekaarmaak en dit saamneem vir die tempel in Jerusalem (Esra 7:16). Artasasta se motief agter sy vrygewigheid is om te verhoed dat die toorn van die God van die hemel oor hom en sy seuns kom (Esra 7:23). Esra sien toe dat hierdie gewyde gawes van silwer en goud noukeurig geweeg word en dat alles aan die priesters in Jerusalem oorhandig word (Esra 8:25-34).

Met die inname van Jerigo in Josua 6:1-27, word daar ook melding gemaak van silwer en goud wat aan JHWH gewy word (Jos 6:19). Josua vermaan die Israeliete om 
hulle daarvan te weerhou om van dit wat aan JHWH behoort, vir hulleself te neem, sodat die kamp van die Israeliete nie self vernietig word nie (Jos 6:18). Josua gee opdrag dat die silwer en goud wat in Jerigo buitgemaak word, in die skatkis van JHWH moet kom (Jos 6:19). Volgens Josua 6:24 word sy opdrag uitgevoer en die silwer en die goud in die skatkis van die huis van JHWH gesit. Die daaropvolgende nederlaag teen Ai word egter aan Akan se ongehoorsaamheid toegeskryf wat van die goud en silwer in sy tent versteek het (Jos 7:20-24). Die stam van Juda word hiermee deur die verteller in 'n negatiewe lig gestel.

Indien die Josua-vertelling teen die agtergrond van die gebeure in post-eksiliese Juda gelees word, is dit moontlik om die onderliggende konflik tussen die verskillende groepe daarin aan te toon. Die inklusiewe groep, bestaande uit die plaaslike bevolking, het waarskynlik die eksklusiewe groep, bestaande uit die teruggekeerde ballinge en die priesters verbonde aan die kultus in Jerusalem, daarvan beskuldig dat hulle hulleself verryk uit die offergawes wat vir JHWH bedoel is en dat hulle daarvoor, volgens hulle eie wet (Esra 7:26) die doodstraf verdien. Vandaar die negatiewe lig waarin Akan en daarmee saam die Juda-stam in die boek Josua geteken word. Die eksklusiewe groep se verweer was waarskynlik, soos wat dit in die boek Esra voorgestel word, dat alle offergawes nougeset vir die tempeldiens aangewend word.

'n Verdere raakpunt tussen die vertellings oor Esra en dié in die boek Josua, handel oor die voorlees van die wet aan die volk. Volgens Von Rad (1957:101) kan die voorlees van die wet beskou word as die hoogtepunt van Esra se optrede. Die wet waarna verwys word hou waarskynlik verband met die wetsgedeeltes van die Pentateug. Otto (2000:210) het reeds gewys op die verband tussen Nehemia 8:1 en Jos 8:31 asook op die ooreenkomste tussen die optrede van Esra en Josua. Volgens Neh 8:1-13 het Esra die wet aan die hele volk (בל-העם) voorgelees (Neh 8:2). Hy het van die wetboek van Moses gebruik gemaak om die wet voor te lees (Neh 8:2). Hy het daaruit voorgelees op die plein voor die Waterpoort (dws in Jerusalem) ten aanhore van mans en vrouens (מאיש ועד־האשה), en elkeen wat kon verstaan (וכל מבין). Dit word 'n byeenkoms van die gemeente (הקהל) genoem (Neh 8:3). Josua lees ook aan die hele Israel (כל־ישראל) uit die wetboek van Moses (ספר תורת משה) voor (Jos 8:31-34). Die volk word ook die gemeente van Israel (כל-קהל ישראל) genoem (Jos 8:35). Daar 
word in Jos 8:35 ook spesifiek melding gemaak van die teenwoordigheid van vroue by hierdie geleentheid. Wat egter opvallend anders is by Josua is dat daar twee keer (Jos 8:33 en 35) spesiaal verwys word na die teenwoordigheid van die vreemdelinge (ג) wat tussen die Israeliete gewoon het. In teenstelling met die boek Esra waar dit in Jerusalem geskied, vind die voorlesing van die wet in die boek Josua by Ebalberg plaas (Jos 8:30).

Die teenwoordigheid van die Levitiese priesters wat die verbondsark van JHWH dra in Jos 8:33 is ook opmerklik. Alhoewel daar ook Leviete teenwoordig is in Esra 8:8-9, word hulle nie priesters genoem nie.

Daar is ook ander raakpunte tussen die twee vertellings soos byvoorbeeld dat beide Josua en Esra van 'n rivier af vertrek. Josua steek die Jordaanrivier saam met al die Israeliete oor (Jos 3:1vv) terwyl Esra en sy geselskap van die Ahawarivier af vertrek na Jerusalem (Esra 8:31). Josua roep die twaalf manne wat deur die volk aangewys is, een uit elke stam, bymekaar om die klippe in die Jordaanrivier op te tel en as 'n herinnering aan die deurtog by Gilgal te stapel (Jos 4:4-9, 20, 21), terwyl Esra die silwer, goud en tempelgereedskap onder twaalf priesters verdeel om dit na die tempel in Jerusalem te neem. Verder speel 'n priester genaamd Eleasar 'n belangrike rol in die boek Josua, veral ten opsigte van die verdeling van die land (Jos 14:1; 17:3; 21:1). Esra is self 'n afstammeling van 'n man met die naam Eleasar (vgl Esra 7:5) en die silwer, goud en tempelgereedskap word in die teenwoordigheid van Eleasar, die seun van Pineas, aan die priester Meremot in die tempel oorhandig (Esra 8:33). Al hierdie raakpunte tussen die boek Josua en die vertellings oor Esra ondersteun die standpunt dat die boek Josua teen die historiese agtergrond van die tyd na die ballingskap gelees moet word.

\subsection{Vertellings oor Nehemia}

Die leidende rol van die priesters met die herstel van die mure om Jerusalem (Neh 3:1, $22,28)$ kom ooreen met die prominente rol wat die priesters in die boek Josua speel tydens die deurtog deur die Jordaanrivier en die inname van Jerigo. Laasgenoemde word eintlik beskryf as 'n kultiese prosessie met die priesters wat die verbondsark dra en op die ramshorings blaas. Die ooreenkomste tussen Jos 6:1-21 en Neh 4:1-23 is opvallend. In Josua gaan dit oor 'n muur wat inmekaar val en in Nehemia oor 'n muur wat gebou word. In Josua word daar op ramshorings geblaas (Jos 6:4, 6, 8, 9, 13, 16, 20) en in Nehemia is 
daar 'n ramshoringblaser naby Nehemia wat daarop blaas as gevaar dreig (Neh 4:18 en 20). In Josua is daar gewapende manskappe (Jos 6:3, 9, 13) en in Nehemia word die bouwerk deur gewapende mans uitgevoer (Neh 4:13, 16-18, 21, 23).

Gesien teen die agtergrond van die botsende denkrigtings in die tyd na die ballingskap, is daar dus ' $n$ interessante verband tussen Nehemia en Josua. Nehemia kan beskou word as verteenwoordigend van die eksklusiewe denkrigting (Smith 1987:98). Al die stappe wat Nehemia neem, wys daarop dat hy 'n rigoris in sy teologie en 'n puris ten opsigte van die nuwe kultiese gemeenskap was. Hy beywer hom vir die uitsluiting van alle vreemdelinge uit dié gemeenskap (Von Rad 1957:100). Hy bou die mure van Jerusalem op met die doel om ander mense uit te sluit uit die gemeenskap wat JHWH dien (Neh 2:20). Josua, as verteenwoordiger van die inklusiewe belangegroep, breek weer die mure van Jerigo af en in die proses word Ragab en haar familie uit die heidennasies in die gemeenskap van hulle wat JHWH dien, opgeneem (Jos 6:25).

Nehemia se optrede teenoor buitestaanders verskil dus grootliks van dié van Josua. Nehemia weier dat Sanballat die Goroniet, Tobija die Ammonietiese amptenaar en Gesem die Arabier, enigsins met die bouwerk aan die muur van Jerusalem te make mag hê. Sy antwoord aan hulle is: ולכם אין־חלק וצדקה וזכרון בירושלם (Neh 2:20). Jos 22:25 verwoord die vrees van die oostelike stamme dat die westelike stamme se nageslag in die toekoms vir hulle sou verhinder om JHWH te dien en dat daar vir hulle gesê sou word dat hulle geen deel het (\$ין־חלק) aan JHWH nie. Die opvallende ooreenkoms in die situasie wat in hierdie twee gedeeltes geskets word, sowel as die woordelikse ooreenkoms van die uitdrukking אין-חלק, dui daarop dat hierdie twee gedeeltes met mekaar in verband gesien kan word. In die boek Josua word die konflik tussen die twee groepe egter deur die bemiddeling van die priesters opgelos (Jos 22:3034), terwyl dit nie die geval is in Nehemia nie. Die gedagte dat die Josua-vertelling die inklusiewe denkrigting se standpunt ten opsigte van buitestaanders teenoor dié van die eksklusiewe denkrigting verteenwoordig, word hierdeur bevestig. Dit word verder gedemonstreer deurdat Nehemia vir Tobija die Ammoniet uitsit uit die kamer waarin hy by die tempel gebly het (Neh 13:4-9), terwyl Josua weer die Gibeoniete aanstel om in die tempel diens te verrig (Jos 9:23,27). Die eksklusiewe denkrigting wat in die vertelling deur Nehemia verteenwoordig word, was waarskynlik gekant teen enige betrokkenheid 
van vreemdelinge en buitestaanders by die kultus. Die inklusiewe denkrigting wat in die vertelling deur Josua verteenwoordig word, het wel daarvoor voorsiening gemaak dat buitestaanders by die kultus betrokke kon raak.

Volgens Neh 13:1 is daar by die inwyding van die muur om Jerusalem uit die wetboek van Moses (ספר פשה) voorgelees. Daarvolgens mag 'n Ammoniet of 'n Moabiet nooit in die gemeente (קהל) van God kom nie (Neh 13:1). Op grond daarvan is almal wat van gemengde herkoms was, van Israel afgeskei (Neh 13:3). Dit verteenwoordig weereens die eksklusiewe denkrigting se standpunt. Net soos in die geval van die wetslesing deur Esra (Neh 8:1-13), kan daar ook hier gewys word op die opvallende verskil ten opsigte van die wetslesing in die Josua-vertelling (Jos 8:30-35).

Dit is naamlik dat daar by laasgenoemde ook vreemdelinge (גר) (קהל) in die gemeente teenwoordig is wanneer die wet voorgelees word (Jos 8:33,35). Die wetslesing deur Josua in die teenwoordigheid van die vreemdelinge, bevestig weereens dat die Josuavertelling die inklusiewe denkrigting se standpunt ten opsigte van vreemdelinge verteenwoordig.

Nog 'n voorbeeld van Nehemia se optrede teenoor buitestaanders, is sy hantering van die huwelike met vroue uit ander nasies (Neh 13:23-28). Nehemia tree hardhandig op teenoor die mans wat met vreemde vroue getroud is (Neh 13:25). Hy laat hulle ook 'n eed aflê (ואששביעם) om nie self met iemand uit die ander nasies te trou nie en ook nie hulle kinders toe te laat om dit te doen nie. In die boek Josua belowe die verkenners weer met 'n eed (השבער) aan Ragab dat hulle haar goed sal behandel en haar en haar familie se lewens sal spaar (Jos 2:12). Dit is juis op grond van hierdie eed dat Josua opdrag gee dat Ragab en haar familie se lewens gespaar moet word en dat hy aan haar blyplek gee tussen die Israeliete (Jos 6:22,25). Die Josua-vertelling bied dus 'n inklusiewe perspektief op die hele saak van huwelike met vroue uit ander nasies, deurdat Ragab, die heidense prostituut, in 'n positiewe lig gestel word. Dit is waarskynlik in reaksie op die onverbiddelike houding vanuit die eksklusiewe kringe in die tyd na die ballingskap jeens mense wat in huwelike met persone uit die omliggende volke betrokke was.

Soos in die geval van Esra, is daar in die Nehemia-vertelling ook aanduidings daarvan dat die leiers in Jerusalem hulleself verryk ten koste van die plaaslike bevolking (Neh 5:1-13). Dit kan ook in verband gebring word met die spanning tussen die 
verskillende belangegroepe in Juda na die ballingskap. Die eksklusiewe groep wat die politieke en godsdienstige mag gehad het in Jerusalem, het die inklusiewe groep wat hoofsaaklik uit die plaaslike bevolking bestaan het, vir hulle eie voordeel uitgebuit. Daar is reeds in die bespreking van die Esra-vertelling aangetoon hoe die boek Josua die geval waarby Akan uit die Judastam betrokke is, hanteer (Jos 7:16-26).

Die Leviete word dikwels vermeld in die Nehemia-vertelling. Dit is egter opmerklik dat daar 'n skerp onderskeid tussen priesters en Leviete gemaak word. In die lys van al die mense wat saam met Serubbabel teruggekeer het (Neh 7:6-69), word daar 'n onderskeid gemaak tussen die priesterlike families (Neh 7:39-42) en die Levitiese families (Neh 7:43-45). In die lys van die inwoners van Jerusalem (Neh 11:1-24) word hulle ook afsonderlik van mekaar genoem. Dieselfde geld ook van die lys van priesters en Leviete wat saam met Serubbabel en Jesua teruggekeer het (Neh 12:1-26). Die Leviete word dikwels as 'n groep naas die priesters genoem (Neh 7:73; 8:14; 9:38; 11:3, 20). Nehemia sien wel toe dat die Leviete ook deel in die voorregte van die tempelpersoneel (Neh 13:10-13), maar hulle word nooit as priesters gereken nie. Die Leviete moet die volk in die wet onderrig (Neh 8:9,10), voorgaan in die gemeente (Neh 9:4-37), vergesel van 'n priester die tiendes insamel (Neh 10:37), sing en musiek maak tydens die inwyding van die muur (Neh 12:27) en die poorte bewaak op die sabbat (Neh $13: 22)$.

Uit bogenoemde is dit duidelik dat die Leviete in die Nehemia-vertelling 'n ondergeskikte rol ten opsigte van die priesters speel. Daarteenoor word die priesters in die Josua-vertelling spesifiek die Levitiese priesters genoem en word dit beklemtoon dat hulle die verbondsark van JHWH gedra het (Jos 3:2; 8:33). Hierdie verskil in benadering tussen die Nehemia-vertelling en die Josua-vertelling ten opsigte van die priesters, is waarskynlik 'n aanduiding van die stryd tussen die priesterhuise in die tyd na die ballingskap. Die Sadokitiese priesters as deel van die eksklusiewe groep, het ná die ballingskap die steun van die Persiese owerheid geniet en het dus ook die kultus in Jerusalem beheer. Die Levitiese priesters wat hoofsaaklik uit die Noordelike heiligdomme kom en wat dus deur die sentralisering van die kultus in Jerusalem gemarginaliseer is, het weer tot die inklusiewe groep behoort.

Smith (1987:110) wys daarop dat daar in die Nehemia-vertelling aan die mense in Juda na die ballingskap 'n nuwe nasionale identiteit toegeken word, naamlik dié van 
Judeërs. Hierdie identiteit het volgens Smith 'n godsdienstige basis van toewyding aan JHWH gehad, maar moes ook ruimte laat vir die assimilasionistiese aspirasies van die inklusiewe denkrigting. Dit het egter die weg gebaan vir die beheer deur die eksklusiewe groep in die toekoms. Die Josua-vertelling reflekteer 'n soortgelyke situasie. Aan die een kant is daar tekens van die eksklusiewe denkrigting soos byvoorbeeld die klem op die absolute gehoorsaamheid aan die wet van Moses. Die inklusiewe denkrigting, aan die ander kant, word weerspieël deur die feit dat daar op sekere momente, soos byvoorbeeld in die geval van die optrede teenoor buitestaanders, daarvan afgewyk word.

\section{GEVOLGTREKKING}

\subsection{Datering van die boek Josua}

Op grond van die voorafgaande, kan daar nou die gevolgtrekking gemaak word dat die finale vorm van die boek Josua wel teen die agtergrond van die tyd na die ballingskap verstaan moet word. Alhoewel die presiese datum van die finale vorm van die boek Josua nie vasgestel kan word nie, kan daar met redelike sekerheid aanvaar word dat die boek in die laat-Persiese tyd gedateer kan word. 'n Datering van die boek Josua in die laat-Persiese tyd bied terselfdertyd 'n verklaring vir die ooreenkomste tussen dié boek en Trito-Jesaja.

Die boek Josua is in sy finale vorm waarskynlik 'n latere verwerking van 'n reeds bestaande werk met die doel om 'n bepaalde belangegroep se ideale te legitimeer. Die ideale van dié belangegroep word deur die boek Josua terug geprojekteer na 'n tydperk heel aan die begin van Israel se geskiedenis om sodoende daaraan gesag te verleen. Dit is 'n poging om tot uitdrukking te bring dat die oorspronklike situasie met die intog die ideale toestand was en dat dit in die tyd van die finalisering van die boek weer nagestreef moes word.

\subsection{Die boek Josua, die Heksateug/Pentateug en die Deuteronomistiese Geskiedenis}

Die resultate van hierdie ondersoek dui daarop dat die boek Josua nie by voorbaat vanweë sy posisie in die kanon net as deel van die Heksateug of die Deuteronomistiese 
Geskiedenis beskou hoef te word nie. Otto (2000) het in 'n groot mate daarin geslaag om die spanning tussen die Pentateug/Heksateug-navorsing en die navorsing oor die Deuteronomistiese Geskiedenis te bowe te kom deur aan te toon dat beide die Pentateug en Heksateug konsepte wat in Deuteronomium voorkom, voortsit en derhalwe hulle oorsprong in Deuteronomium het. Deuteronomium kan beskou word as die wieg van die Pentateug. Die resultate van hierdie studie ondersteun Otto se standpunt.

Met die na-eksiliese redaksionele verbinding van die Josua-vertelling met Deuteronomium en die oordrag van die leierskap van Moses op Josua, wat in die vertellinge oor die inname van die land in die boek Josua reeds voor-Deuteronomisties vasgelê is, tree die tema van die intog in die land op die voorgrond. Die redaksionele geskiedenis van Deuteronomium, die Heksateug en die Pentateug bevestig dus die hipotese dat die finale samestelling van die boek Josua in die tyd na die ballingskap plaasgevind het.

\subsection{Die Josua-vertelling as 'n kontra-narratief}

Op grond van die voorafgaande, kan die afleiding gemaak word dat die finale vorm van die Josua-vertelling as 'n kontra-narratief op die na-eksiliese Sionsteologie, bedoel was. Dit blyk uit die volgende aspekte van die Josua-vertelling:

- Jerusalem word uitgeskryf en die heiligdomme van die noorde word beklemtoon.

- Israel se vyande word nie almal vernietig nie. Sommige buitestaanders wat optree soos wat van 'n Israeliet verwag sou word, se lewens word gespaar.

- Die nakoming van die wet is wel belangrik. Dit mag egter nie in die pad staan daarvan dat buitestaanders ook ingesluit word in die volk van JHWH nie.

- Die ideale leier van Israel is nie 'n koninklike figuur uit die geslag van Dawid nie, maar iemand uit die profetiese tradisie van Moses. Dié leier is iemand wat soos Moses optree maar wat tog ook afwyk van die Mosaïese wet - veral ten opsigte van 
die hantering van buitestaanders. Dit is 'n charismatiese leier wat nie op grond van afkoms as leier aangestel is nie, maar wat met die titel שבד יהוד beskryf word.

- Die hele land word aan al die Israeliete gegee as die vervulling van JHWH se belofte. Daarom is die besit van die land nie iets waarop net 'n sekere deel van die volk kan aanspraak maak nie. Die hele land geld as 'n heiligdom waar JHWH aanbid word. Daarom kan die een groep nie die ander uitsluit van die diens van JHWH, of dit as hulle alleenreg beskou om JHWH te dien nie.

- Die eenheid van die volk van JHWH word beklemtoon. Daar moet gepoog word om verskille tussen die groepe binne die volk van JHWH te oorbrug en om sódoende uiteindelik versoening teweeg te bring. Die identiteit van die ware Israeliet word nie volgens afkoms bepaal nie maar deur die land. Mense wat in die land woon en wat JHWH dien, word as deel van sy volk beskou, al is hulle nie volgens afkoms deel van die volk Israel nie.

\subsection{Die belangegroep verantwoordelik vir die boek Josua}

Die belangegroep wat verantwoordelik was vir die finale vorm van die Josua-verhaal was waarskynlik 'n gemarginaliseerde, na-eksiliese profetegroep ${ }^{2}$ wat in konflik met die godsdienstige elite van die Jerusalemse tempel verkeer het. Hulle het aansluiting gevind by die plaaslike bevolking wat nie in ballingskap weggevoer is nie en wat verbintenisse met die omliggende volke gehad het. In hulle verset teen Jerusalem en die tempel het hulle van die standpunt af uitgegaan dat JHWH op enige plek gedien kan word en het hulle hulle beroep op die ou tradisies van die heiligdomme uit veral die noorde van die land. Hulle het die gevaar daarvan ingesien om uitgesluit te word uit die godsdienstige, politieke en ekonomiese mag wat die terugkerende ballinge vanweë die Persiese owerheid geniet het. Hulle het die verwagting gekoester van 'n leier soos Moses. Hulle het hulle toegelê op die stiptelike onderhouding van die wet, met die uitsondering dat hulle ruimte gelaat het vir die insluiting van mense uit ander volke. Hulle het hulleself beskou as die ware dienaars van JHWH. Hulle het hulle beywer vir versoening met hulle

\footnotetext{
${ }^{2}$ Vergelyk paragraaf 3 waar die ooreenkomste tussen Trito-Jesaja en die boek Josua hanteer word.
} 
volksgenote deur wie hulle verwerp is. In hulle stryd met die eksklusiewe groep van die tempel, het hulle aansluiting gevind by die Levitiese priesters wat ook ná die ballingskap hulle bevoorregte posisie in die tempel kwyt was en wat deur die Sadokitiese priesters, wat op hulle beurt weer die ondersteuning van die Persiese owerheid geniet het, uitgeskuif is of tot 'n ondergeskikte posisie gedegradeer is.

\subsection{Die implikasies van die ondersoek vir Bybelse geskiedskrywing}

Dit is duidelik dat die boek Josua nie gelees moet word as 'n historiese weergawe van Israel se inname van die land nie. Die boek is veel eerder 'n poging om iets weer te gee van die krisis waarin die volk van JHWH hulleself bevind het in die tyd na die ballingskap. Dit was 'n tyd toe daar verskillende antwoorde gegee is op die vraag na die identiteit van Israel as die volk van JHWH. Die boek Josua is een só 'n antwoord vanuit die perspektief van een bepaalde belangegroep soos wat dit hierbo weergegee is. Volgens Albertz (1994:464) is die godsdiens van Israel in die na-eksiliese periode juis gekenmerk deur 'n stryd oor die identiteit van die gemeenskap.

In die na-eksiliese tyd was die vraag oor wie tot Israel behoort en wie nie, 'n wesentlike vraag en nie 'n periferiese aangeleentheid nie (Von Rad 1957:103). Israel was nou nie meer net 'n volk wat deur afkoms bepaal is nie. Dit was die wet wat al hoe meer bepaal het wie tot Israel behoort en wie nie. Diegene wat van vreemde afkoms was, moes uitgesluit word of onder sekere omstandighede ingesluit word as proseliete. Wat en wie deel van Israel is, was 'n saak van die interpretasie van die wet. Israel het nou afskeid geneem van die geskiedenis as 'n konstituerende element van hulle identiteit, maar nie van hulle verhouding met JHWH nie. Deur die wet het die wil van JHWH vir Israel tydloos geword.

In 'n sekere sin is die boek Josua in reaksie teen hierdie opvatting in die naeksiliese tyd. Dit wil voorkom of die boek Josua die weg baan vir mense van 'n ander afkoms om ook deel te wees van die volk van JHWH, alhoewel daar nog nie by Josua sprake is van 'n algemene universalisme soos in die geval van Trito-Jesaja nie. Von Rad (1957:312) wys ook op 'n ander aspek wat as deurslaggewend beskou is vir Israel se identiteit en dit is naamlik om 'n deel van die land te besit. Om deel te hê aan JHWH is om deel te hê (חלק) aan die die land (vgl Jos 22:25, 27; Jes 61:7; Neh 2:20). 
'n Verdere implikasie van hierdie ondersoek is dat die Josua-figuur wat in die finale vorm van die boek Josua na vore kom, ook soos Moses en Samuel as 'n "literary creation" (Breytenbach 2000:58) beskou moet word. Oor die vraag of daar 'n historiese persoon soos Josua was, kan daar maar net gespekuleer word. Dit is sekerlik so dat dit wel moontlik is dat daar 'n historiese figuur met die naam Josua bestaan het en dat daar rondom sy figuur ' $\mathrm{n}$ aantal tradisies versamel is. Dit kan egter aanvaar word dat, wie ook al in die hooglande van Palestina geleef het teen ongeveer $1000 \mathrm{vC}$, hulle nie gedink, gelyk en opgetree het soos dié wat deur die Bybelse skrywers daar geplaas is nie. Die feit dat daar in die Bybelse verhale na historiese persone verwys word, beteken nog nie dat dit die bedoeling van die outeur was om die gebeure histories korrek en akkuraat te beskryf nie.

\subsection{Slotopmerking}

Wanneer die boek Josua teen die agtergrond van die na-ballingskap tyd en as 'n reaksie teen die eksklusiwiteit van die Sionsteologie in dié tyd gelees word, verkry dit besondere betekenis. In die eerste plek bevorder die boek Josua 'n desentralisasie van godsdienstige gesag. Die opvatting dat een groep oor die beheer van die aanbidding van JHWH beskik deur die tempel in Jerusalem, word in die boek negatief beoordeel. JHWH kan volgens die boek Josua op enige plek gedien word en nie net by die tempel nie, aangesien die hele land as 'n heiligdom vir JHWH in besit geneem word. Tweedens vertoon die boek Josua 'n merkwaardige openheid teenoor en aanvaarding van buitestaanders soos Ragab en die Gibeoniete in die godsdienstige gemeenskap. Die boek dien as 'n oproep om diegene wat nog buite die geloofsgemeenskap verkeer, daarby in te sluit. Die boek Josua is inderdaad ook 'n getuienis van hoe daar versoening kan plaasvind tussen verskillende groepe binne 'n bepaalde geloofsgemeenskap wat op grond van godsdienstige aangeleenthede verdeel

is. Ten slotte bied die boek in die figuur van Josua 'n voorbeeld aan van wat bedoel word met 'n ware dienaar van JHWH. Dit is naamlik iemand wat die wet getrou nakom, maar terselfdertyd ook deernis het met buitestaanders. 


\section{Literatuurverwysings}

Albertz, R 1994. A history of Israelite religion in the Old Testament period, Volume II: From the exile to the Maccabees. Louisville: Westminister John Knox.

Auld, A G 1978. Cities of refuge in Israelite tradition. JSOT 10, 26-40.

Auld, A G 1980. Joshua, Moses and the land: Tetrateuch-Pentateuch-Hexateuch in a generation since 1938. Edinburgh: T\&T Clark.

Auld, A G 1995. Reading Josua after Kings, in Davies, J et al (eds), Words remembered, texts renewed: Essays in honour of John FA Sawyer. Sheffield: Sheffield Academic Press. (JSOT Supplement 195).

Beuken, W A M 1989a. Jesaja, Deel III A. Nijkerk: Callenbach. (POT).

Beuken, W A M 1989b. Jesaja, Deel III B. Nijkerk: Callenbach. (POT).

Beuken, W A M 1990. The main theme of Trito-Isaiah: "The servants of YHWH". JSOT 47, 67-87.

Botterweck, G J \& Ringgren, H (eds) 1997. Theological dictionary of the Old Testament, Volume 8. Grand Rapids: Eerdmans.

Breytenbach, A P B 2000. Who is behind the Samuel narrative? in De Moor \& Van Rooy 2000:51-61.

Curtis, A H W 1994. Joshua. Sheffield: Sheffield Accademic Press.

Deist, F E 1987. Die Heksateug, in Bosman, H L \& Loader, J A (reds), Vertellers van die Ou Testament. Kaapstad: Tafelberg.

Deist, F E \& Le Roux, J H (reds) 1987. Rewolusie en rë̈nterpretasie. Kaapstad: Tafelberg.

De Moor, J C \& Van Rooy, H F (eds) 2000. Past, present, future: The Deuteronomistic History and the Prophets. (Oudtestamentische Studiën XLIV).

Fritz, V 1994. Das Buch Josua. Tubingen: Mohr (HAT).

Gottwald, N K 1985. The Hebrew Bible: A socio-literary introduction. Philadelpia: Fortress.

Hamlin, E J 1983. Inheriting the land: A commentary on the book of Josua. Grand Rapids: Eerdmans. (International Theological Commentary)

Halpern, B 1975. Gibeon: Israelite diplomacy in the conquest era. $C B Q$ 37, 303-316.

Halpern, B 1981. The centralization formula in Deuteronomy. VT 31/1, 20-38. 
Hanson, P D 1989. The dawn of apocalyptic. Philadelphia: Fortress.

Koole, J L 1995. Jesaja, III. Kampen: Kok (COT).

Koorevaar, H J 1990. De opbouw van het boek Jozua. Brussel: Heverlee.

Laato, A 1992. Josiah and David redivivus: The historical Josiah and the messianic expectations of exilic and postexilic times. Stockholm: Almqvist \& Wiksell.

Lindeque, G C 2001. Die boek Josua gelees teen 'n na-eksiliese agtergrond. DD-proefskrif, Universiteit van Pretoria.

Mayes, A D H 1983. The story of Israel between settlement and exile: A redactional study of the Deuteronomistic History. London: SCM.

Mitchell, G 1993. Together in the land: A reading of the book of Joshua. Sheffield: Sheffield Academic Press. (JSOT Supplement 134).

Nelson, R D 1981a. Josiah in the book of Joshua. JBL 100/4, 531-540.

Nelson, R D 1981b. The double redaction of the Deuteronomistic History. Sheffield: Sheffield Academic Press. (JSOT Supplement 18).

Nelson, R D 1997. Joshua: A commentary. Louisville: Westminster John Knox. (OTL).

Nicholson, E 1963. The centralisation of the cult in Deuteronomy. VT XIII, 380- 389.

Noort, E 1998a. Das Buch Josua: Forschungsgeshichte und Problemfelder. Darmstadt: Wissenschafliche Buchgesellschaft.

Noort, E 1998b. Zu Stand und Perspektiven: Der Glaube Israels zwischen Religionsgeschichte und Theologie. Der Fall Josua 24. (VT Supplement LXXIII).

Noort, E 2000. Joshua: The history of reception and hermeneutics, in De Moor \& Van Rooy 2000:199-215.

Noth, M 1971. Das Buch Josua. Tubingen: Mohr (HAT).

Noth, M 1981. The Deuteronomistic History. Sheffield: Sheffield Academic Press. (JSOT Supplement 15).

Otto, E 2000. Das Deuteronomium im Pentateuch und Hexateuch: Studien zur Literaturgeschichte von Pentateuch und Hexateuch im Lichte des Deuteronomiumrahmens. Tübingen: Mohr Siebeck.

Ottosson, M 1991. Josuaboken - en programskrift for davidisk restauration. Uppsala: Almqvist \& Wiksell.

Polzin, R 1980. Moses and the Deuteronomist: A literary study of the Deuteronomic History. New York: Seabury. 
Von Rad, G 1938. Das formgeschichtliche Problem des Hexateuch. Stuttgart: Kohlhammer. (Beiträge zur Wissenschaft vom Alten und Neuen Testament, 4. Folge Heft 26.)

Von Rad, G 1943. Verheissenes Land und Jahwes Land im Hexateuch. Zeitschrift des Deutschen Palästina-Vereins 191-204.

Von Rad, G 1957. Theologie des Alten Testaments, I: Die Theologie der geschichtlichen Uberlieferungen Israels. München: Chr Kaiser.

Von Rad, G 1960. Theologie des Alten Testaments, II. Die Theologie der prophetischen Uberlieferungen Israels. München: Chr Kaiser.

Smith, M 1987. Palestinian parties and politics that shaped the Old Testament. London: SCM.

Soggin, J A 1972. Joshua: A commentary. London: SCM. (OTL).

Spronk, K 1994. Jozua: Een praktische Bijbelverklaring. Kampen: Kok. (Tekst en Toelichting).

Strange, J 1993. The book of Josua: A Hasmonean manifesto? VT Supplementum 50, 136-141. 